\title{
Cold coffee seeds storage with different water content
}

\author{
Amanda Carvalho Penido ${ }^{1}$ (D), Venícius Urbano Vilela Reis ${ }^{1}$ (iD), Édila Maria de Rezende ${ }^{2}$ (D) \\ Debora Kelli Rocha1 $^{1}$, João Almir Oliveira ${ }^{1}$ (D), Sttela Dellyzete Veiga Franco da Rosa ${ }^{3}$
}

\author{
${ }^{1}$ Universidade Federal de Lavras/UFLA, Departamento de Agricultura/DAG, Lavras, MG, Brasil \\ ${ }^{2}$ Universidade Federal de Uberlândia/UFU, Monte Carmelo, MG, Brasil \\ ${ }^{3}$ Empresa Brasileira de Pesquisa Agropecuária/Embrapa, Embrapa Café, Brasília, DF, Brasi \\ Contact authors: apenidoufla@gmail.com; veniciusreis@gmail.com; em_rezende@hotmail.com; deborarocha.agro@gmail.com; jalmir@ufla.br; sttela.rosa@embrapa.br \\ Received in November 5, 2020 and approved in April 20, 2021
}

\section{ABSTRACT}

Coffee seeds are classified as intermediate because they have low tolerance to desiccation and low longevity. Consequently, moisture control and storage conditions are important factors in maintaining the physiological quality of these seeds. Thus, the objective in this work was to evaluate the water content effect on coffee seed longevity. Seeds of five Coffea arabica cultivars from the 2016/2017 crop were used. Part of the harvested seeds was dried in the shade until reach $12 \%$ moisture and the other part did not go through drying process, remaining with $40 \%$ water content. The seeds were stored in a cold

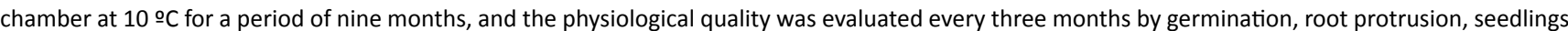
with expanded cotyledonary leaves, seedling dry mass and enzymatic analysis of catalase enzymes and superoxide dismutase. Regardless of the cultivar, wet seeds coffee storage provides better maintenance of physiological quality for up to nine months. Seedling vigor is reduced throughout the storage period, regardless of seed water content.

Key words: Coffea arabica; Moisture; Seed quality; Storage.

\section{INTRODUCTION}

Seeds longevity is considered one of the most important characteristics, not only for the plant adaptation in edaphoclimatic changes environments, but also for agriculture and the biodiversity conservation (Sano et al., 2016). It is known that seeds of Coffea arabica species have limited conservation, due to their intermediate behavior in not tolerating desiccation, and depending on the storage environment (Coelho et al., 2015; Dussert et al., 2018; Ellis; Hong; Roberts, 1990; Fantazzini et al., 2018).

In this sense, seed quality is defined by factors that determine the potential of a lot after sowing or during storage, through four attributes, which are: genetic, physical, sanitary and physiological (Marcos Filho, 2015). Physiological quality is related to longevity, germination and vigor. Among the attributes of the physiological quality of seeds, vigor is one of the most relevant factors because it is associated with uniformity of germination, emergence and seedling growth in the field, overcoming adverse cultivation conditions (Rossi; Cavariani; França-Neto, 2017).

Among the environmental conditions, factors such as temperature, relative humidity and pathogens presence, are important aspects that influence the viability and longevity of seeds during the storage period (Groot et al., 2012; Petrenko, 2014). Among these factors, seed water content stands out as a key factor, as it directly influences the seed quality, and consequently, its correct adjustment is considered a constant challenge for arabica coffee seed producers (Nasiro; Shimber; Mohammed, 2017).
Some studies were carried out to evaluate the coffee seeds performance under specific moisture conditions, drying and storage. In the study by Brandão Júnior et al. (2002), it was observed that arabica coffee seeds maintained their physiological quality when stored with $15 \%$ moisture in impermeable packaging at $10{ }^{\circ} \mathrm{C}$ for a period of nine months, however, seeds with $50 \%$ moisture had a decrease at constant rates in the germination percentage at the same period. Rosa et al. (2005) observed that regardless the drying method, water contents higher than $35 \%$ are harmful to the canephora coffee seeds physiological quality maintenance. Araujo et al. (2008) observed that arabica coffee seeds with high moisture (31.5\%) can be stored for a period of nine months in permeable packaging. Regarding drying, Abreu et al. (2014) observed that arabica coffee seeds dried slowly in the shade, up to $20 \%$ moisture, provided correct quality conservation for up to twelve months of storage. Despite the different studies involving the effects of moisture and drying on the coffee seeds physiological quality, the results obtained are still contradictory and inconclusive (Santos; Von Pinho; Rosa, 2013).

Guimarães and Mendes (1998) report that the emergence of coffee seeds occurs between 50 and 60 days after sowing, and under temperatures below $25^{\circ} \mathrm{C}$, it can take from 90 to 120 days. This fact is relevant, since the coffee seeds harvested in the months of may/june, will gain the producer at the beginning of the cold season. Thus, research is necessary to improve the storage potential of coffee seeds, in order to obtain vigorous seedlings and in a season whose climate is more suitable for implantation the farming. 
Due to the coffee culture importance in the Brazil, and its significant contribution to the international market, it is necessary to develop techniques that allow adequate storage resulting in sowing seeds with high quality mainly at the most favorable time for the coffee seedlings development, since the seed production does not coincide with this period. Thus, the objective in this work was to evaluate the seed longevity of five Coffea arabica cultivars with different water content.

\section{MATERIAL AND METHODS}

The work was carried out at the Central Seed Analysis Laboratory of the Agriculture Department at the Federal University of Lavras (UFLA). Seeds from 2017 harvest, Coffea arabica L. species, cultivars Catuaí Vermelho IAC 144, Mundo Novo IAC 376/4, Catiguá MG2, MGS Aranãs and Topázio MG 1190, provided by the Agricultural Research Company of Minas Gerais (EPAMIG), were used.

In the work, seeds with two water contents were used, being freshly harvested seeds that were already commercialized by the company with the water content varying from 29 to $41 \%$ among cultivars, and dry seeds, wherein part of the seeds of these cultivars was dried in the shade until the water content was close to $12 \%$.

After obtaining the seeds in the two water contents, they were packed in separate portions for each storage period, disposed in conventional raffia bags and still packaged with another waterproof plastic bag. The storage was carried out in a cold chamber at $10{ }^{\circ} \mathrm{C}$, with samples taken every three months for a period of nine months to determine the physiological quality, according to the tests and determinations described below.

Water content determination: The water content was carried out by the drying oven method, at $105 \pm 3{ }^{\circ} \mathrm{C} / 24 \mathrm{~h}$ (Brasil, 2009), with two samples of $20 \mathrm{~g}$ per repetition. The results obtained, based on wet weight, were expressed as a percentage.

Germination test: It was carried out using four repetitions of 50 seeds, distributed on paper for germination, moistened with an amount of water equivalent to 2.5 times the weight of dry paper. The seeds were kept in a germinator regulated at a temperature $30{ }^{\circ} \mathrm{C}$ and the percentage of normal seedlings was evaluated after 30 days, following the criteria established in the Rule for Seed Analysis (Brasil, 2009).

Root protrusion: Conducted 15 days after starting germination test, the seedlings that presented the radicle emergence were computed, and the results were expressed as a percentage.

Seedlings with expanded cotyledonary leaves: The test was performed 45 days after the beginning of the germination test, in which the seedlings that presented the fully expanded cotyledonary leaves were computed and the results were expressed as a percentage.

Seedling dry mass: Held 45 days after the beginning of the germination test, the hypocotyl-radicle axes of normal seedlings were separated and packaged in paper bags, placed in an oven with air circulation at $60{ }^{\circ} \mathrm{C}$, for five days. After this period the dry mass of the seedlings' shoots and roots was determined, the results being expressed in grams per seedling.

Enzymatic analysis: At each storage period, quantification of catalase (CAT) and superoxide dismutase (SOD) enzymes activity was determined. The seeds were macerated in liquid nitrogen and polyvinylpolypyrrolidone (PVPP) insoluble. Samples $0.05 \mathrm{~g}$ of the macerated material were homogenized in $1.5 \mathrm{~mL}$ of the extraction buffer composed of potassium phosphate $100 \mathrm{mM}$ (pH 7.0), EDTA $0.1 \mathrm{mM}$ and ascorbic acid $10 \mathrm{mM}$ and water. The homogenized material was centrifuged at $13.000 \mathrm{~g}$ for 20 minutes at $4{ }^{\circ} \mathrm{C}$ and the supernatant collected.SOD activity was based on the enzymes ability to inhibit the photoreduction of nitrotetrazolium blue (NBT) in a reaction medium containing potassium phosphate $100 \mathrm{mM}$ (pH 7.8), methionine $14 \mathrm{mM}$, EDTA $0.1 \mu \mathrm{M}$, NBT $75 \mu \mathrm{M}$ and riboflavin $2 \mu \mathrm{M}$ (Giannopolitis; Ries, 1977). The readings were performed on a plate spectrophotometer at 560 $\mathrm{nm}$. One SOD unit corresponds to the amount of enzyme capable of inhibiting in 50\% the NBT photoreduction under the assay conditions. CAT activity was determined according to Azevedo et al. (1998), with modifications, estimated by the decrease in absorbance at $240 \mathrm{~nm}$ for 3 minutes in a reaction medium containing potassium phosphate $100 \mathrm{mM}(\mathrm{pH} 7.0)$ and $\mathrm{H}_{2} \mathrm{O}_{2} 12.5 \mathrm{mM}$.

The experimental design was completely randomized, in a $2 \times 4 \times 5$ factorial scheme, with two levels of water content (wet and dry), four storage periods (0, 3, 6 and 9 months) and five cultivars used. The data were subjected to variance analysis and the average comparison, with a significance level 5\%, it was performed using the Scott Knott test, with the help of the SISVAR $^{\circledR}$ software (Ferreira, 2011). Quantitative data for the storage period were analyzed using by observed averages.

\section{RESULTS}

The seed water content average values of the five cultivars examined in this work, determined after each storage period are contained in Table 1.

The initial profile characterization of the five Coffea arabica cultivars was done using the freshly harvested seed germination rate. It can be seen from the results in Table 2, that there was no significant difference among the germination percentages between the cultivars. All materials in question have higher germination values than that established by the Ministry of Agriculture for marketing, which is currently $70 \%$ (Brasil, 2012). 
Table 1: Seed water content average values $\left(w b^{*}\right)$ of different Coffea arabica cultivars obtained after each storage period.

\begin{tabular}{|c|c|c|c|}
\hline \multirow{2}{*}{ Cultivar } & \multirow{2}{*}{$\begin{array}{l}\text { Storage } \\
\text { (months) }\end{array}$} & \multicolumn{2}{|c|}{ Moisture (\%) } \\
\hline & & Wet & Dry \\
\hline \multirow{4}{*}{ Catuaí Vermelho IAC 144} & 0 & 39.17 & 12.89 \\
\hline & 3 & 39.16 & 12.58 \\
\hline & 6 & 39.44 & 12.99 \\
\hline & 9 & 39.06 & 12.91 \\
\hline \multirow{4}{*}{ Mundo Novo IAC 376/4 } & 0 & 38.25 & 11.36 \\
\hline & 3 & 38.48 & 11.51 \\
\hline & 6 & 38.67 & 11.96 \\
\hline & 9 & 38.40 & 11.68 \\
\hline \multirow{4}{*}{ Catiguá MG2 } & 0 & 29.80 & 12.30 \\
\hline & 3 & 29.78 & 12.62 \\
\hline & 6 & 29.89 & 12.45 \\
\hline & 9 & 29.14 & 12.57 \\
\hline \multirow{4}{*}{ MGS Aranãs } & 0 & 40.39 & 11.65 \\
\hline & 3 & 40.90 & 11.56 \\
\hline & 6 & 40.79 & 11.90 \\
\hline & 9 & 40.95 & 11.83 \\
\hline \multirow{4}{*}{ Topázio MG 1190} & 0 & 41.01 & 12.30 \\
\hline & 3 & 41.08 & 12.15 \\
\hline & 6 & 41.88 & 12.34 \\
\hline & 9 & 41.11 & 12.12 \\
\hline
\end{tabular}

*wb: wet base.

Table 2: Profile characterization of the different Coffea arabica cultivars by the germination test (freshly harvested seeds). Rates were assessed on day 30 after starting germination.

\begin{tabular}{cc}
\hline Cultivar & Germination (\%) \\
\hline Catuaí Vermelho IAC 144 & 80 \\
Mundo Novo IAC 376/4 & 78 \\
Catiguá MG2 & 77 \\
MGS Aranãs & 81 \\
Topázio MG 1190 & 84 \\
\hline
\end{tabular}

The averages did not statistically differ (Scott Knott test at $5 \%$ probability).

By the variance analysis results, there was a triple interaction of the factors under study for all variables analyzed in the seeds physiological quality evaluation with respect to the different cultivars, to different water contents and to different storage periods.

With the exception of Mundo Novo cultivar, no difference was observed in the germination rates of wet and dry seeds as long as they were not stored. With storage, in the three subsequent periods, wet seeds show better results when compared to dry seeds in most cultivars (Table 3 ).
Table 3: Percentage of seed germination of different Coffea arabica cultivars with different water contents and submitted to storage.

\begin{tabular}{|c|c|c|c|}
\hline \multirow{2}{*}{$\begin{array}{l}\text { Storage } \\
\text { (months) }\end{array}$} & \multirow{2}{*}{ Cultivars } & \multicolumn{2}{|c|}{ Moisture } \\
\hline & & Wet & Dry \\
\hline \multirow{5}{*}{0} & Catuaí Vermelho IAC 144 & $80 \mathrm{Aa}$ & $78 \mathrm{Aa}$ \\
\hline & Mundo Novo IAC 376/4 & $78 \mathrm{Aa}$ & $70 \mathrm{Bb}$ \\
\hline & Catiguá MG2 & $77 \mathrm{Aa}$ & $81 \mathrm{Aa}$ \\
\hline & MGS Aranãs & $81 \mathrm{Aa}$ & $81 \mathrm{Aa}$ \\
\hline & Topázio MG 1190 & $84 \mathrm{Aa}$ & $83 \mathrm{Aa}$ \\
\hline \multirow{5}{*}{3} & Catuaí Vermelho IAC 144 & $81 \mathrm{Aa}$ & $79 \mathrm{Ba}$ \\
\hline & Mundo Novo IAC 376/4 & $80 \mathrm{Aa}$ & $69 \mathrm{Cb}$ \\
\hline & Catiguá MG2 & $82 \mathrm{Aa}$ & $71 \mathrm{Cb}$ \\
\hline & MGS Aranãs & $84 \mathrm{Aa}$ & $76 \mathrm{Bb}$ \\
\hline & Topázio MG 1190 & $85 \mathrm{Aa}$ & $86 \mathrm{Aa}$ \\
\hline \multirow{5}{*}{6} & Catuaí Vermelho IAC 144 & $86 \mathrm{Aa}$ & $81 \mathrm{Ab}$ \\
\hline & Mundo Novo IAC 376/4 & $81 \mathrm{Ba}$ & $65 \mathrm{Bb}$ \\
\hline & Catiguá MG2 & $78 \mathrm{Ba}$ & $70 \mathrm{Bb}$ \\
\hline & MGS Aranãs & $84 \mathrm{Aa}$ & $77 \mathrm{Ab}$ \\
\hline & Topázio MG 1190 & $86 \mathrm{Aa}$ & $83 \mathrm{Aa}$ \\
\hline \multirow{5}{*}{9} & Catuaí Vermelho IAC 144 & $80 \mathrm{Ba}$ & $75 \mathrm{Ba}$ \\
\hline & Mundo Novo IAC 376/4 & $77 \mathrm{Ba}$ & $71 \mathrm{Bb}$ \\
\hline & Catiguá MG2 & $66 \mathrm{Cb}$ & $81 \mathrm{Aa}$ \\
\hline & MGS Aranãs & $86 \mathrm{Aa}$ & $74 \mathrm{Bb}$ \\
\hline & Topázio MG 1190 & $87 \mathrm{Aa}$ & $81 \mathrm{Aa}$ \\
\hline
\end{tabular}

The averages followed by the same capital letter in the column for each storage period and lower case in the line did not differ by the Scott Knott test at $5 \%$ probability.

When analyzing the wet seeds of the different cultivars, it could be noted that for up to three months of storage, the the same quality was maintained until, after six months, growing differences between the cultivars could be observed (Table 3 ). This was not the case with dry seeds, which already after three months of storage, showed greater differences among cultivars in relation to seed germination.

In general, the cultivars had a small variation in the germination percentage over the storage period (Figure 1). In the case of wet seeds, there is a downward trend between six and nine months of storage, but with the exception of the Catiguá cultivar, the seeds remained with a germination percentage superior the minimum standard required by the Ministry of Agriculture for marketing, which is currently $70 \%$ (Brasil, 2012).

It was observed for the root protrusion percentage, that rates were similar to those observed in the germination test. There was no difference among cultivars in the results of wet and dry seeds until three months of storage, with the exception of cv. Mundo Novo IAC 376/4.The latter showed a limited protrusion rate in the dry seeds as compared to the wet seeds, already from the beginning of storage (Table 4). 

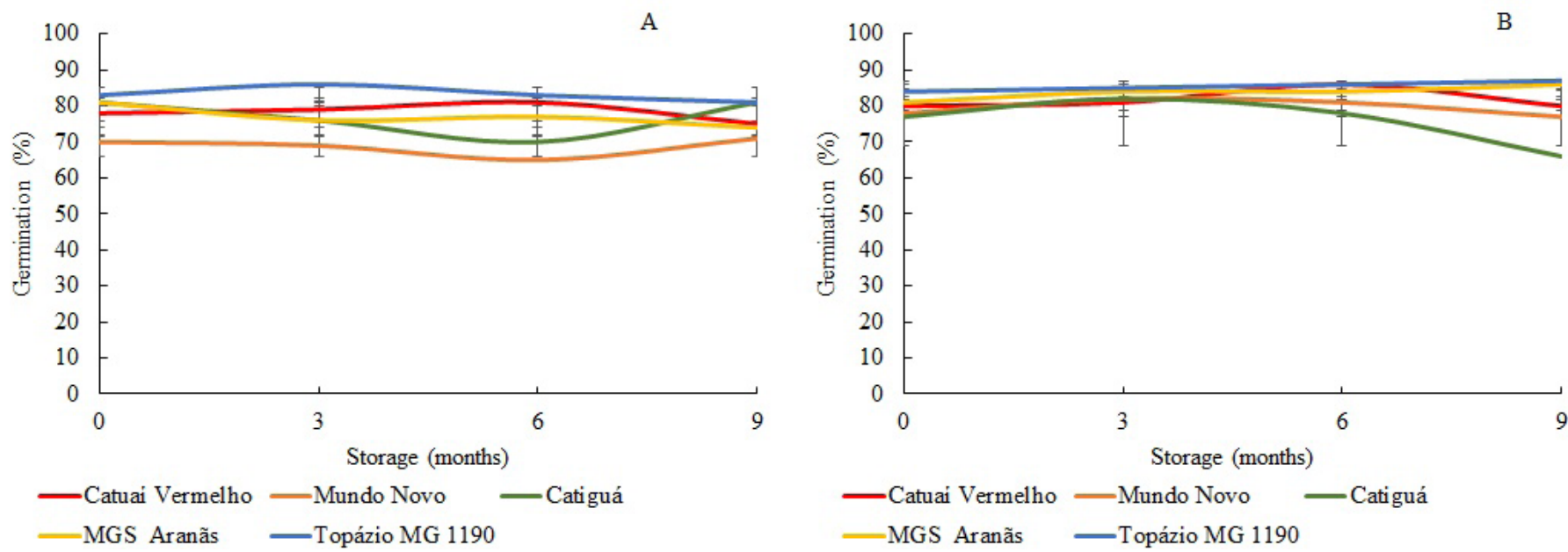

Figure 1: Germination rate (\%) dry (A) and wet (B) seeds of Coffea arabica cultivars during storage.

Table 4: Rate of seeds with root protrusion of Coffea arabica cultivars with different water contents and submitted to storage. Rates were assessed on day 15 after starting germination.

\begin{tabular}{|c|c|c|c|}
\hline \multirow{2}{*}{$\begin{array}{l}\text { Storage } \\
\text { (months) }\end{array}$} & \multirow{2}{*}{ Cultivars } & \multicolumn{2}{|c|}{ Moisture } \\
\hline & & Wet & Dry \\
\hline \multirow{5}{*}{0} & Catuaí Vermelho IAC 144 & $94 \mathrm{Aa}$ & $93 \mathrm{Aa}$ \\
\hline & Mundo Novo IAC 376/4 & $90 \mathrm{Aa}$ & $83 \mathrm{Bb}$ \\
\hline & Catiguá MG2 & $90 \mathrm{Aa}$ & $91 \mathrm{Aa}$ \\
\hline & MGS Aranãs & $91 \mathrm{Aa}$ & $92 \mathrm{Aa}$ \\
\hline & Topázio MG 1190 & $92 \mathrm{Aa}$ & $94 \mathrm{Aa}$ \\
\hline \multirow{5}{*}{3} & Catuaí Vermelho IAC 144 & $96 \mathrm{Aa}$ & $93 \mathrm{Aa}$ \\
\hline & Mundo Novo IAC 376/4 & $95 \mathrm{Aa}$ & $89 \mathrm{Ab}$ \\
\hline & Catiguá MG2 & $93 \mathrm{Aa}$ & $91 \mathrm{Aa}$ \\
\hline & MGS Aranãs & $94 \mathrm{Aa}$ & $93 \mathrm{Aa}$ \\
\hline & Topázio MG 1190 & $93 \mathrm{Aa}$ & $95 \mathrm{Aa}$ \\
\hline \multirow{5}{*}{6} & Catuaí Vermelho IAC 144 & $91 \mathrm{Aa}$ & $89 \mathrm{Ba}$ \\
\hline & Mundo Novo IAC 376/4 & $91 \mathrm{Aa}$ & $78 \mathrm{Cb}$ \\
\hline & Catiguá MG2 & $88 \mathrm{Ab}$ & $94 \mathrm{Aa}$ \\
\hline & MGS Aranãs & $91 \mathrm{Aa}$ & $87 \mathrm{Ba}$ \\
\hline & Topázio MG 1190 & $89 \mathrm{Aa}$ & $89 \mathrm{Ba}$ \\
\hline \multirow{5}{*}{9} & Catuaí Vermelho IAC 144 & $88 \mathrm{Ba}$ & $82 \mathrm{Bb}$ \\
\hline & Mundo Novo IAC 376/4 & $89 \mathrm{Ba}$ & $81 \mathrm{Bb}$ \\
\hline & Catiguá MG2 & $76 \mathrm{Cb}$ & $91 \mathrm{Aa}$ \\
\hline & MGS Aranãs & $95 \mathrm{Aa}$ & $84 \mathrm{Bb}$ \\
\hline & Topázio MG 1190 & $96 \mathrm{Aa}$ & $95 \mathrm{Aa}$ \\
\hline
\end{tabular}

The averages followed by the same capital letter in the column for each storage period and lower case in the line do not differ from each other by the Scott Knott test at $5 \%$ probability.

Between six and nine months storage period, quality reduction in the dried seeds, can be observed, when compared to the wet ones, in most of the cultivars used in the study. In addition, when comparing cultivars, in wet seeds only at 9 months, it is possible to observe difference in quality among them. In the dried seeds, it can be seen that after six months of storage, there is a difference in the cultivars regarding physiological quality.

In general, it is possible to note that in most cultivars used in this study, the seeds did not lose their potential for root protrusion, with little variation over the nine months in which the seeds were stored, as shown in Figure 2.

In the results of the seedlings percentage with expanded cotyledonary leaves (Table 5), there was also a triple interaction of the factors under study.

It was observed that, in general, wet seeds have a higher percentage of expanded cotyledonary leaves when compared to seeds that have undergone the drying process. For most cultivars, wet seeds, at nine months of storage, showed superior results to dry seeds, showing that wet seeds storage provides better maintenance of the physiological quality and seeds vigor (Table 5). This result was also observed in the germination test.

In Figure 3, it can be observed that there is a reduction in coffee seedling vigor of most cultivars over the storage period, in the two water levels evaluated in the study.

For the dry matter root and shoot variables, the best results were also observed in wet seeds, as seen in Table 6 . In the freshly harvested seedlings obtained from seeds, it is possible to observe better results in wet seeds when compared to dry seeds, and during storage this fact can also be noticed. It is possible to verify that cultivars present differences in vigor already in the first evaluations, in freshly harvested seeds, for the two studied water contents and, during the storage period, these differences are also observed.

It is also observed by the results of Figures 4 and 5, that, in general, the cultivars lost their vigor during storage, presenting smaller accumulations of roots and shoot dry matter in the freshly harvested seeds and without storage. That same result was observed in the evaluation of expanded cotyledonary leaves, concluding there was a reduction in seed vigor during storage. 

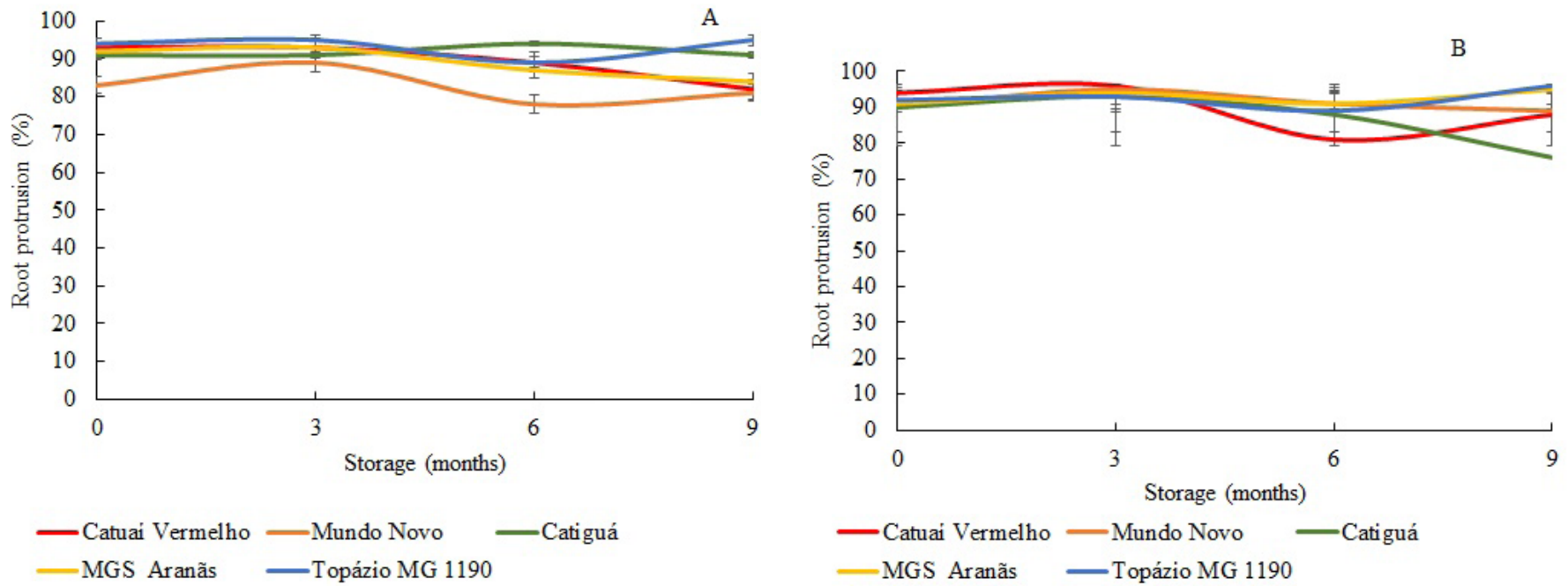

Figure 2: Root protrusion (\%) dry (A) and wet (B) seeds of Coffea arabica cultivars during storage.

Table 5: Seedlings percentage with expanded cotyledonary leaves at 45 days after sowing (\%), seeds of Coffea arabica cultivars with different water contents and submitted to storage.

\begin{tabular}{|c|c|c|c|}
\hline \multirow{2}{*}{$\begin{array}{l}\text { Storage } \\
\text { (months) }\end{array}$} & \multirow{2}{*}{ Cultivars } & \multicolumn{2}{|c|}{ Moisture } \\
\hline & & Wet & Dry \\
\hline \multirow{5}{*}{0} & Catuaí Vermelho IAC 144 & $77 \mathrm{Aa}$ & $67 \mathrm{Bb}$ \\
\hline & Mundo Novo IAC 376/4 & $76 \mathrm{Aa}$ & $58 \mathrm{Cb}$ \\
\hline & Catiguá MG2 & $74 \mathrm{Aa}$ & $75 \mathrm{Aa}$ \\
\hline & MGS Aranãs & $68 \mathrm{Ba}$ & $58 \mathrm{Cb}$ \\
\hline & Topázio MG 1190 & $80 \mathrm{Aa}$ & $77 \mathrm{Aa}$ \\
\hline \multirow{5}{*}{3} & Catuaí Vermelho IAC 144 & $64 \mathrm{Ba}$ & $63 \mathrm{Ba}$ \\
\hline & Mundo Novo IAC 376/4 & $57 \mathrm{Ba}$ & $47 \mathrm{Cb}$ \\
\hline & Catiguá MG2 & $62 \mathrm{Ba}$ & $49 \mathrm{Cb}$ \\
\hline & MGS Aranãs & $69 \mathrm{Aa}$ & $59 \mathrm{Bb}$ \\
\hline & Topázio MG 1190 & $73 \mathrm{Aa}$ & $76 \mathrm{Aa}$ \\
\hline \multirow{5}{*}{6} & Catuaí Vermelho IAC 144 & $85 \mathrm{Aa}$ & $77 \mathrm{Ab}$ \\
\hline & Mundo Novo IAC 376/4 & $77 \mathrm{Aa}$ & $57 \mathrm{Cb}$ \\
\hline & Catiguá MG2 & $68 \mathrm{Ba}$ & $63 \mathrm{Ba}$ \\
\hline & MGS Aranãs & $84 \mathrm{Aa}$ & $68 \mathrm{Bb}$ \\
\hline & Topázio MG 1190 & $82 \mathrm{Aa}$ & $78 \mathrm{Aa}$ \\
\hline \multirow{5}{*}{9} & Catuaí Vermelho IAC 144 & $67 \mathrm{Ba}$ & $63 \mathrm{Ba}$ \\
\hline & Mundo Novo IAC 376/4 & $72 \mathrm{Ba}$ & $54 \mathrm{Cb}$ \\
\hline & Catiguá MG2 & $41 \mathrm{Cb}$ & $71 \mathrm{Aa}$ \\
\hline & MGS Aranãs & $83 \mathrm{Aa}$ & $52 \mathrm{Cb}$ \\
\hline & Topázio MG 1190 & $85 \mathrm{Aa}$ & $63 \mathrm{Bb}$ \\
\hline
\end{tabular}

The averages followed by the same capital letter in the column for each storage period and lower case in the line do not differ from each other by the Scott Knott test at $5 \%$ probability.
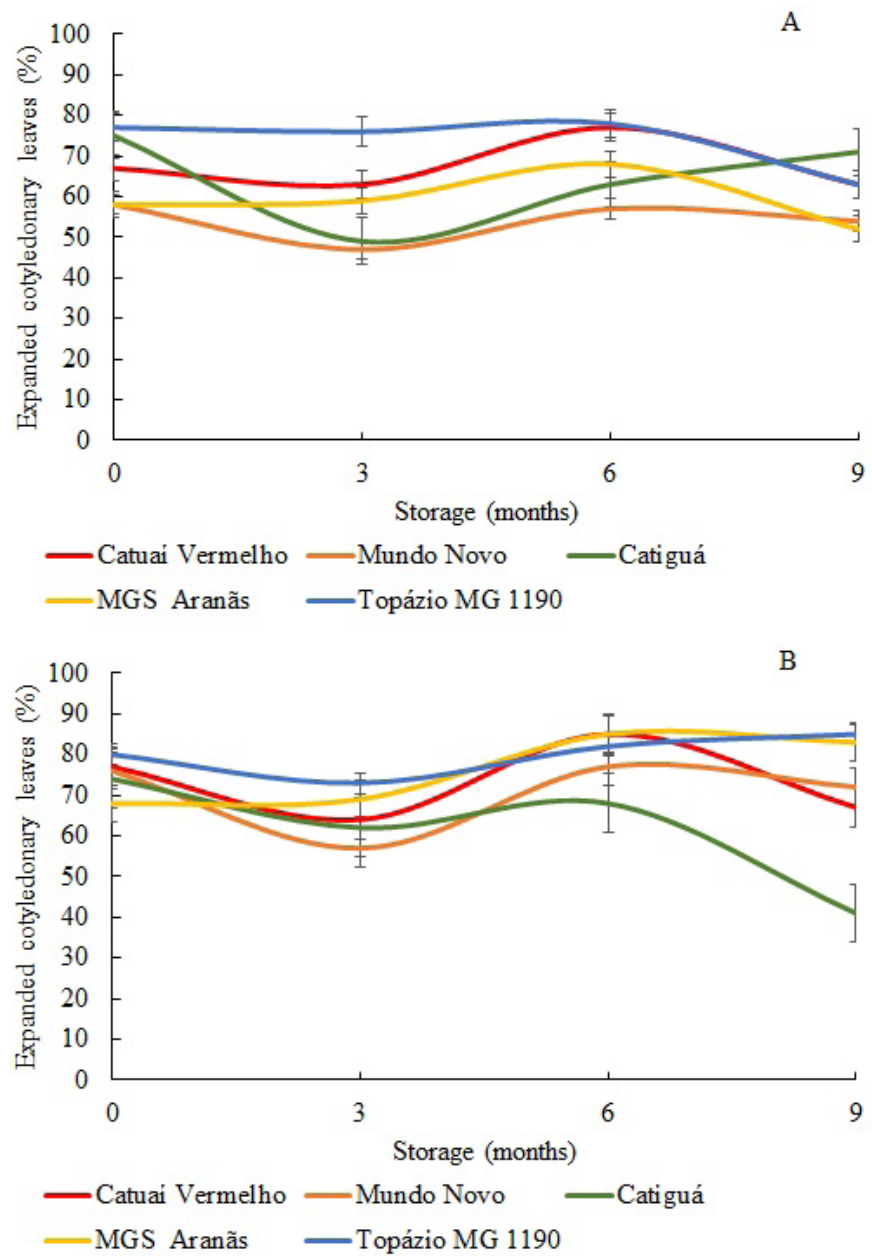

Figure 3: Seedlings percentage with expanded cotyledonary leaves (\%) after 45 days of sowing dry (A) and wet (B) seeds of five Coffea arabica cultivars during storage. 
Table 6: Root dry matter weight (RDM) and shoot dry matter (SDM) of seedlings from seeds of Coffea arabica cultivars with different water content and submitted to storage.

\begin{tabular}{|c|c|c|c|c|c|}
\hline \multirow{3}{*}{$\begin{array}{l}\text { Storage } \\
\text { (months) }\end{array}$} & \multirow{3}{*}{ Cultivars } & \multicolumn{2}{|c|}{ RDM (g) } & \multicolumn{2}{|c|}{$\operatorname{SDM}(g)$} \\
\hline & & \multicolumn{2}{|c|}{ Moisture } & \multicolumn{2}{|c|}{ Moisture } \\
\hline & & Wet & Dry & Wet & Dry \\
\hline \multirow{5}{*}{0} & Catuaí Vermelho IAC 144 & $0.35 \mathrm{Aa}$ & $0.26 \mathrm{Bb}$ & $1.60 \mathrm{Aa}$ & $1.35 \mathrm{Ab}$ \\
\hline & Mundo Novo IAC 376/4 & $0.35 \mathrm{Aa}$ & $0.29 \mathrm{Bb}$ & $1.80 \mathrm{Aa}$ & $1.36 \mathrm{Ab}$ \\
\hline & Catiguá MG2 & $0.29 \mathrm{Ba}$ & $0.35 \mathrm{Aa}$ & $1.31 \mathrm{Bb}$ & $1.57 \mathrm{Aa}$ \\
\hline & MGS Aranãs & $0.39 \mathrm{Aa}$ & $0.26 \mathrm{Bb}$ & $1.42 \mathrm{Ba}$ & $1.04 \mathrm{Bb}$ \\
\hline & Topázio MG 1190 & $0.28 \mathrm{Ba}$ & $0.32 \mathrm{Aa}$ & $1.51 \mathrm{Ba}$ & $1.50 \mathrm{Aa}$ \\
\hline \multirow{5}{*}{3} & Catuaí Vermelho IAC 144 & $0.20 \mathrm{Ba}$ & $0.20 \mathrm{Ba}$ & $1.21 \mathrm{Ba}$ & $1.16 \mathrm{Ba}$ \\
\hline & Mundo Novo IAC 376/4 & $0.19 \mathrm{Ba}$ & $0.17 \mathrm{Ba}$ & $1.35 \mathrm{Ba}$ & $1.05 \mathrm{Bb}$ \\
\hline & Catiguá MG2 & $0.23 \mathrm{Ba}$ & $0.15 \mathrm{Bb}$ & $1.22 \mathrm{Ba}$ & $0.87 \mathrm{Bb}$ \\
\hline & MGS Aranãs & $0.29 \mathrm{Aa}$ & $0.23 \mathrm{Aa}$ & $1.59 \mathrm{Aa}$ & $1.25 \mathrm{Ab}$ \\
\hline & Topázio MG 1190 & $0.21 \mathrm{Bb}$ & $0.28 \mathrm{Aa}$ & $1.40 \mathrm{Ba}$ & $1.47 \mathrm{Aa}$ \\
\hline \multirow{5}{*}{6} & Catuaí Vermelho IAC 144 & $0.32 \mathrm{Aa}$ & $0.30 \mathrm{Aa}$ & $1.62 \mathrm{Ba}$ & $1.53 \mathrm{Aa}$ \\
\hline & Mundo Novo IAC 376/4 & $0.34 \mathrm{Aa}$ & $0.21 \mathrm{Bb}$ & $1.79 \mathrm{Aa}$ & $1.25 \mathrm{Bb}$ \\
\hline & Catiguá MG2 & $0.27 \mathrm{Aa}$ & $0.23 \mathrm{Ba}$ & $1.43 \mathrm{Ba}$ & $1.27 \mathrm{Ba}$ \\
\hline & MGS Aranãs & $0.33 \mathrm{Aa}$ & $0.28 \mathrm{Aa}$ & $1.89 \mathrm{Aa}$ & $1.51 \mathrm{Ab}$ \\
\hline & Topázio MG 1190 & $0.28 \mathrm{Aa}$ & $0.31 \mathrm{Aa}$ & $1.73 \mathrm{Aa}$ & $1.59 \mathrm{Aa}$ \\
\hline \multirow{5}{*}{9} & Catuaí Vermelho IAC 144 & $0.13 \mathrm{Cb}$ & $0.19 \mathrm{Aa}$ & $0.98 \mathrm{Ca}$ & $1.17 \mathrm{Aa}$ \\
\hline & Mundo Novo IAC 376/4 & $0.22 \mathrm{Ba}$ & $0.20 \mathrm{Aa}$ & $1.28 \mathrm{Ba}$ & $1.15 \mathrm{Aa}$ \\
\hline & Catiguá MG2 & $0.09 \mathrm{Cb}$ & $0.23 \mathrm{Aa}$ & $0.64 \mathrm{Db}$ & $1.27 \mathrm{Aa}$ \\
\hline & MGS Aranãs & $0.34 \mathrm{Aa}$ & $0.13 \mathrm{Bb}$ & $1.89 \mathrm{Aa}$ & $1.03 \mathrm{Ab}$ \\
\hline & Topázio MG 1190 & $0.24 \mathrm{Ba}$ & $0.16 \mathrm{Bb}$ & $1.60 \mathrm{Ba}$ & $1.16 \mathrm{Ab}$ \\
\hline
\end{tabular}

The averages followed by the same capital letter in the column for each storage period and lower case in the line for each variable, do not differ from each other by the Scott Knott test at 5\% probability.
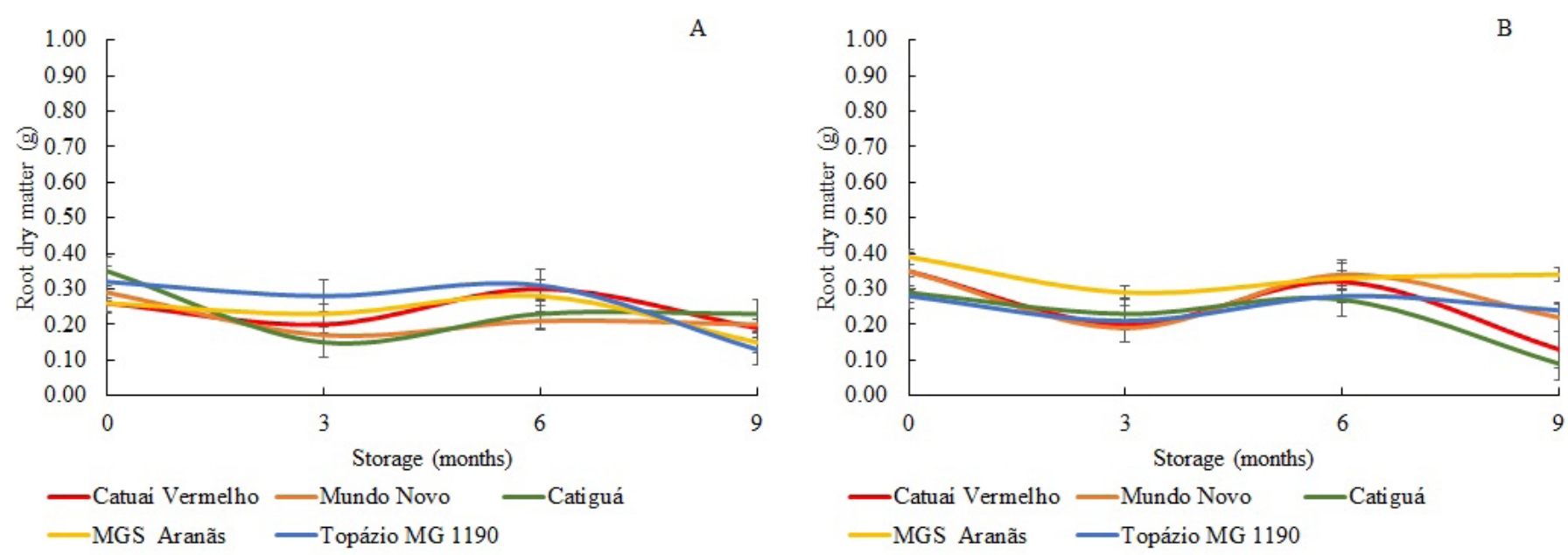

Figure 4: Dry matter weight of seedling roots (g) 45 days after germination dry (A) and wet (B) seeds of five Coffea arabica cultivars during storage.

For the analysis of catalase (CAT) enzymatic activity and superoxide dismutase (SOD) there was a significant effect isolated from the storage factor. Figure $6 \mathrm{~A}$ shows that catalase enzyme activity increased in the three and six months of storage, and at nine months a decrease in the enzyme activity is observed. Figure $6 \mathrm{~B}$ shows a linear increase in the superoxide dismutase enzyme activity during storage. At nine months it is possible to observe the highest rate of this enzyme activity. 
A
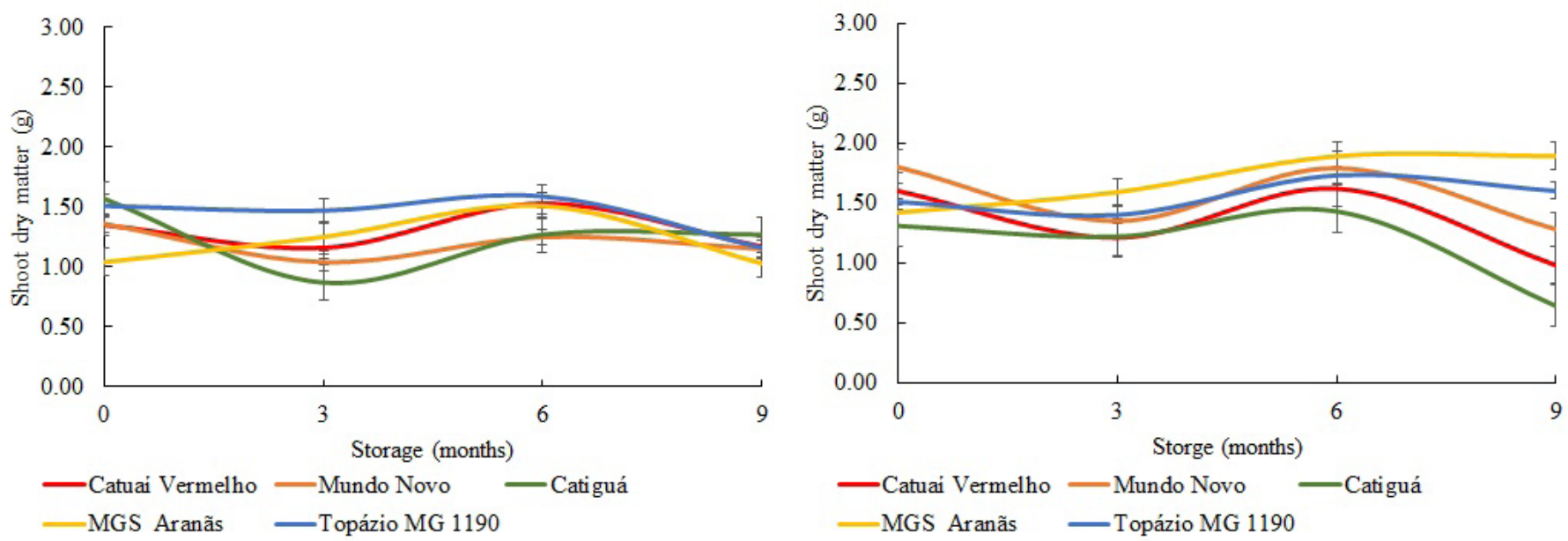

Figure 5: Dry matter weight of seedling shoot (g) 45 days after sowing dry (A) and wet (B) seeds of Coffea arabica cultivars during storage.
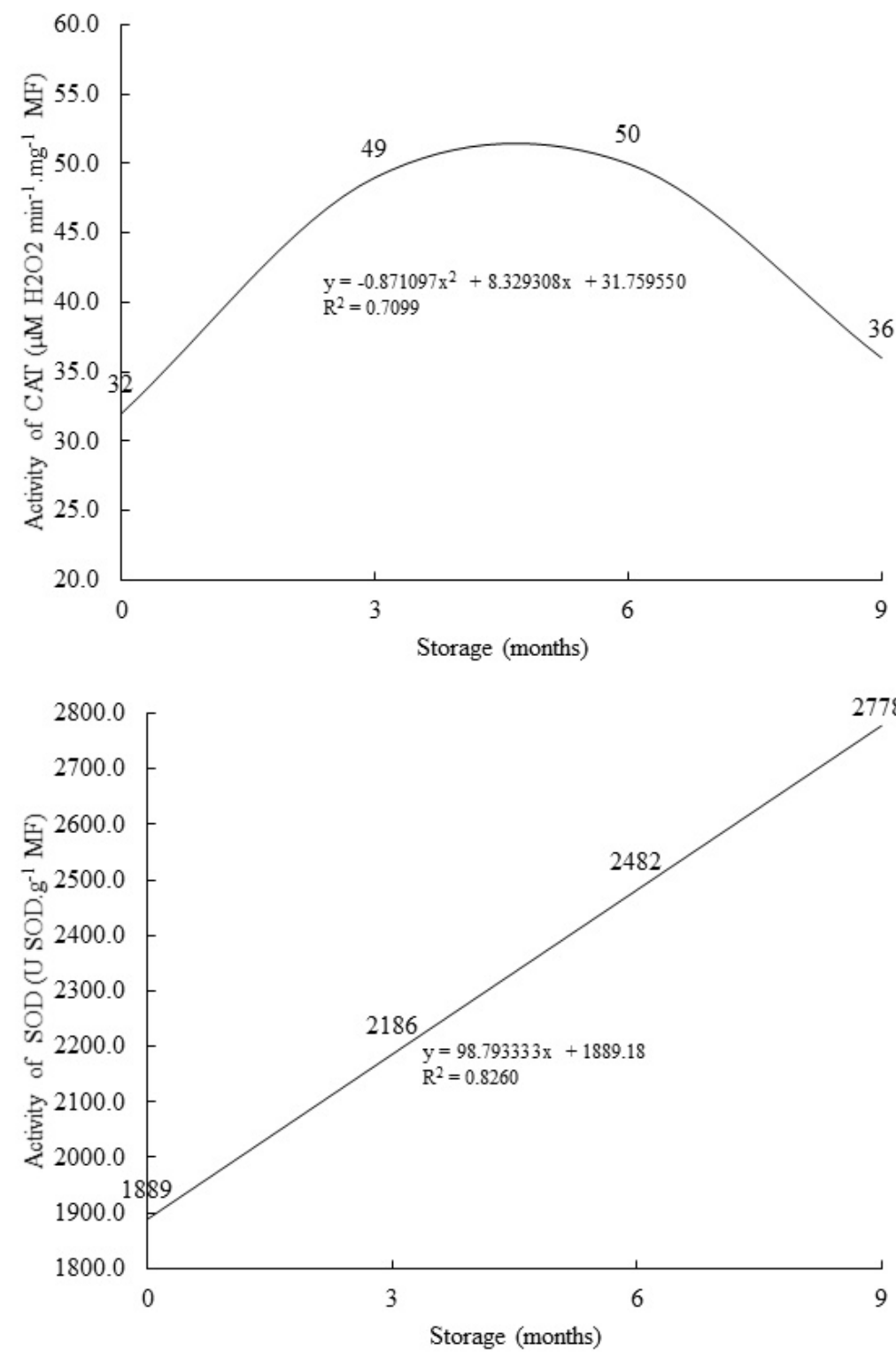

Figure 6: Activity of catalase enzymes (CAT) superoxide dismutase (SOD) over the Coffea arabica seeds storage period. 


\section{DISCUSSION}

It is observed that there were few changes in the seeds water content during the storage period, obviously due to the use of impermeable packaging. The type of packaging used for the storage of seeds has great importance in maintaining the viability and vigor of the seeds, being directly related to the physiological quality (Baudet, 2003; Smaniotto et al., 2020).

In this study, coffee seeds are sensitive to moisture loss and, therefore, wet seeds have better results when stored at 10 ${ }^{\circ} \mathrm{C}$ in impermeable packaging, maintaining their quality even when stored.Nasiro, Shimber and Mohammed (2017) observed that there is a highly significant interaction between storage conditions, storage time and coffee seeds water content. The seeds with the highest water content performed better than those were dried at lower water levels, and the cooled environment $\left(15{ }^{\circ} \mathrm{C}\right)$ was also superior when compared to the environment at ambient conditions. Lopes et al. (2014), working with arabica coffee seeds storage, observed that seeds with a higher water content preserved their viability for a longer period during storage than those with a lower water content. These data corroborate with that was observed in this study.

Braccini et al. (1999) observed coffee seeds with high water content $(35 \%)$ had favorable germination results during storage. In the work of Vieira et al. (2007), it was also observed that seeds without drying and those dried slowly, stored in a cold chamber, they had similar results in relation to the conservation of germination power, with smaller linear reduction in germination until nine months of storage. On the other hand, in this study, this fact was not observed, where seeds that were dried in the shade had more reductions in the germination.

According Sano et al. (2016) at the beginning of storage, oxidative events lead to breaking dormancy, promoting germination capacity, and may be considered as a beneficial mechanism to improve seed vigor. Subsequently, if the storage occurs for prolonged periods, the accumulation of cellular oxidative damage progressively induces the loss of seed vigor and, thus, the reduction of the germination capacity. In coffee culture, it is common for seeds to improve their germination potential up to three months of storage and, subsequently, over the storage period, there is a gradual fall in their potential, a fact that can be observed in this study.

The reduction in coffee seedlings vigor is expected, as soon after the physiological seeds maturity, there is a series of physiological, physical, biochemical changes in the seeds and, as a consequence, there is a reduction in their vigor. The deterioration can be accelerated by several factors, e.g for Arabidopsis, the high temperature of the storage location and also the seed water content (Schausberger et al., 2019).

For most vigor tests evaluated in this work, a reduction in the seeds quality was observed after the storage period, diverging from germination test results, in which there was maintenance of coffee seeds quality. Similar effects were found in the works by Abreu et al. (2014) and Vieira et al. (2007), in which the stored coffee seeds showed a reduction in vigor throughout the storage period, regardless of the drying process. That same result was observed in the work by Coelho et al. (2015), on what the storage period did not affect germination, but it reduced coffee seed vigor.

Both enzymes evaluated in the study are part of the protection system against seed spoilage. The superoxide dismutase enzyme (SOD) catalyzes the superoxide radical dismutation in $\mathrm{H}_{2} \mathrm{O}_{2}$ and $\mathrm{O}_{2}$ and catalase (CAT) can break down $\mathrm{H}_{2} \mathrm{O}_{2}$ into $\mathrm{H}_{2} \mathrm{O}$ and $\mathrm{O}_{2}$ (Carneiro et al., 2011), which is an important defense against free radicals. Thus, catalase expression increase occurs to eliminate the accumulation of $\mathrm{H}_{2} \mathrm{O}_{2}$ resulting from lipid peroxidation in seeds (Santos et al., 2016). According to Salla et al. (2016), the increase of antioxidant enzymes activity, including SOD and CAT is one of the first lines of defense against oxidative stress in cells. This fact confirms what was observed in the study, that the seeds will deteriorate during the storage period and, consequently, there is a reduction in their vigor.

\section{CONCLUSIONS}

Throughout a period of nine months storage of wet seeds provides a better maintenance of the physiological quality, as evaluated for five different Coffea arabica cultivars.

There is a seed vigor decrease over the storage period, regardless of the water content studied.

There is a different behavior among the Coffea arabica cultivars evaluated for deterioration during storage.

\section{REFERENCES}

ABREU, L. A. D. S. et al. Behavior of coffee seeds to desiccation tolerance and storage. Journal of Seed Science, 36(4):399-406, 2014.

ARAUJO, R. F. et al. Conservação de sementes de café (Coffea arabica L.) despolpado e não despolpado. Revista Brasileira de Sementes, 30(3):71-78, 2008.

AZEVEDO, R. A. D.et al. Response of antioxidant enzymes to transfer from elevated carbon dioxide to air and ozone fumigation, in the leaves and roots of wild-type and a catalase-deficient mutant of barley. Physiology Plantarum, 104(1):280-292, 1998.

BAUDET, L. Armazenamento de sementes. In: PESKE, S. T.; ROSENTAL, M. D.; ROTA, G. R. Sementes: Fundamentos científicos e tecnológicos. Pelotas: UFPel, p.369-418, 2003. 
BRACCINI, L. A. de et al. Efeito do grau de umidade e do tipo de embalagem na conservação de sementes de café (Coffea arabica L.). Acta Scientiarum. Agronomy, 21(3):571-577, 1999.

BRANDÃO JÚNIOR, D. S. et al. Tolerância à dessecação de sementes de cafeeiro (Coffea arabica L.). Revista Brasileira de Sementes, 24(2):7-23, 2002.

BRASIL. Ministério da Agricultura, Pecuária e Abastecimento - Secretaria de Defesa Agropecuária. Regras para análise de sementes. Brasília: MAPA/ACS, 2009. 395p.

BRASIL. Ministério da Agricultura, Pecuária e Abastecimento. Instrução Normativa no 35, de 29 de novembro de 2012. Anexo XXII. Brasília: MAPA/ACS, 2012. 10p.

CARNEIRO, M. M. L. C. et al. Atividade antioxidante e viabilidade de sementes de girassol após estresse hídrico e salino. Revista Brasileira de Sementes, 33(4):752-761, 2011.

COELHO, S. V. B. et al. Alterações fisiológicas e bioquímicas em sementes de café secas em sílica gel e soluções salinas saturadas. Pesquisa Agropecuária Brasileira, 50(6):483-491, 2015.

DUSSERT, S. et al. Integrative analysis of the late maturation programme and desiccation tolerance mechanisms in intermediate coffee seeds. Journal of experimental botany, 69(7):1583-1597, 2018.

ELLIS, R. H.; HONG, T. D.; ROBERTS, E. H. An intermediate category of seed storage behavior? :I., coffee. Journal of Experimental Botany, 41(230):1167-1174, 1990.

FANTAZZINI, T. B. et al. Associação entre o teste de envelhecimento artificial e o armazenamento natural de sementes de café. Journal of Seed Science, 40(2):164$172,2018$.

FERREIRA, D. F. SISVAR: A computer statistical analysis system. Ciência e Agrotecnologia, 35(6):1039-1042, 2011.

GIANNOPOLITIS, C. N.; RIES, S. K. Superoxide dismutases: I. Occurrence in higher plants. Plant Physiology, 59(2):309-314, 1977.

GROOT, S. P. C. et al. Seed storage at elevated partial pressure of oxygen, a fast method for analysing seed ageing under dry conditions. Annals of Botany, 110(60):1149-1159, 2012.

GUIMARÃES, R. J.; MENDES, A. N. G. Produção de mudas de cafeeiro. In: MENDES, A. N. G.; GUIMARÃES, R. G. Cafeicultura empresarial: Produtividade e qualidade. Lavras: UFLA/FAEPE, p.1-60, 1998. (Texto acadêmico).
LOPES, J. C. et al. Spatial distribution of physiological quality of Arábica coffee seeds to cultivate Catuai. Idesia (Arica), 32(2):65-74, 2014.

MARCOS-FILHO, J. Fisiologia de sementes de plantas cultivadas. Londrina, PR: ABRATES, 2015. 600p.

NASIRO, K.; SHIMBER, T.; MOHAMMED, A. Germination and seedling growth rate of coffee (Coffea arabica L.) seeds as influenced by initial seed moisture content, storage time and storage condition. International Journal of Agriculture Biosciences, 6(6):304-310, 2017.

PETRENKO, V. Influence of storage conditions on germination of winter wheat seeds (Triticum aestivum L.) in relation to agriculture systems. Žemès Ūkio Mokslai, 21(3):173-180, 2014.

ROSA, S. D. V. F. D. et al. Effects of different drying rates on the physiological quality of Coffea canephora Pierre seeds. Brazilian Journal of Plant Physiology, 17(2):199-205, 2005.

ROSSI, R. F.; CAVARIANI, C.; FRANÇA-NETO, J. B. Vigor de sementes, população de plantas e desempenho agronômico de soja. Revista de Ciências Agrárias, 60(3):215-222, 2017.

SALLA, S. et al. Antioxidant activity of papaya seeds extracts against oxidative stress induced by $\mathrm{H}_{2} \mathrm{O}_{2}$ in HepG2 cells. Food Science and Technology, 66:293-297, 2016.

SANO, N. et al. Staying alive: Molecular aspects of seed longevity. Plant and Cell Physiology, 57(4):660-674, 2016.

SANTOS, G. C.; VON PINHO, E. V. R.; ROSA, S. D.V.F. Gene expression of coffee seed oxidation and germination processes during drying. Genetics and Molecular Research, 12(4):6968-6982, 2013.

SANTOS, H. O. D. et al. Physiological and biochemical aspects of castor beans seeds deterioration stored in different packaging conditions and temperatures. Journal of Seed Science, 38(3):241-247, 2016.

SCHAUSBERGER, C. et al. Abscisic acid-determined seed vigour differences do not influence redox regulation during ageing. Biochemical Journal, 476(6):965-974, 2019.

SMANIOTTO, T. A. S. et al. Qualidade fisiológica de sementes de girassol armazenadas em diferentes embalagens. Research, Society and Development, 9(6):e47963466, 2020.

VIEIRA, A. R. et al. Armazenamento de sementes de cafeeiro: Ambientes e métodos de secagem. Revista Brasileira de Sementes, 29(1):76-82, 2007. 